\title{
Fusarielin A as an Anti-angiogenic and Anti-proliferative Agent: Basic Biological Characterization
}

\author{
Haruka Fujimoto, Hiroshi Aoyama, Tomomi Noguchi-Yachide, Yuichi Hashimoto, and \\ Hisayoshi KOBAYASHI* \\ Institute of Molecular \& Cellular Biosciences, The University of Tokyo; 1-1-1 Yayoi, Bunkyo-ku, Tokyo 113-0032, Japan. \\ Received October 22, 2007; accepted December 17, 2007; published online December 18, 2007
}

Fusarielin A shows anti-angiogenic activity in the human umbilical vein endothelial cell (HUVEC) tube formation assay. Structural development studies indicated the importance of the hydroxyl groups in this molecule. $A^{3} \mathrm{H}$-labeled derivative and a fluorescent affinity-labeling agent were prepared and used to examine the cellular distribution and biological behavior of fusarielin $\mathrm{A}$. tein

Key words fusarielin A; anti-angiogenic activity; tritium-labeling; human umbilical vein endothelial cell; HL-60; binding pro-

Natural products that influence cell proliferation/differentiation and signal transduction systems are of great interest as candidate anti-tumor agents. Generally, isolation of bioactive natural products based on some specific biological activity requires a specific bioassay system that reflects the corresponding biological activity. ${ }^{1-6)}$ For example, tubulin function disruptors (inhibitors of tubulin polymerization or depolymerization) have generally been isolated with the aid of microtubule assembly assay, ${ }^{1-4)}$ while signal transduction inhibitors have generally been isolated with the guidance of inhibition assays of specific enzymes, such as protein kinases and phosphatases. ${ }^{5,6)}$ On the other hand, a bioassay system that could simultaneously detect various kinds of cell function modulators, including cell proliferation inhibitors, cell differentiation modulators, signal transduction modulators, and so on, would be a superior tool to discover unique bioactive compounds, even if it provided no information as to their specific molecular targets/mechanisms.

One such broad-spectrum bioassay method utilizes the conidia of Pyricularia oryzae (P. oryzae) P-2b (Fig. 1).,8) Germination of conidia of $P$. oryzae $\mathrm{P}-2 \mathrm{~b}$ is sensitive to various kinds of bioactive compounds (details will be published elsewhere). For example, tubulin polymerization inhibitors, including rhizoxin, ${ }^{1)}$ griseofulvin, ${ }^{2)}$ nocodazole ${ }^{3)}$ and phomopsidin, ${ }^{4)}$ generally show morphological effects, such as curling, on mycelia germinated from conidia of P. oryzae P$2 \mathrm{~b}$ [Fig. 1, panels (c) - (f)].

Using the $P$. oryzae $\mathrm{P}-2 \mathrm{~b}$ assay method, we have isolated an antifungal antibiotic, fusarielin A (1: FSA) (Fig. 2), from a culture of Fusarium sp. K432.7) The effect of FSA (1) in this bioassay [Fig. 1, panel (b)] was similar to those elicited by compounds that interfere with microtubule function, including rhizoxin [panel (c)], ${ }^{1)}$ griseofulvin [panel (d)], ${ }^{2)}$ nocodazole [panel (e)], ${ }^{3)}$ and phomopsidin [panel (f) $]^{4}$ (Fig. 1). However, FSA (1) did not inhibit the assembly or disassembly of microtubule protein prepared from porcine brain. ${ }^{7)}$ Further investigation revealed that FSA (1) shows cell typeselective anti-proliferative activity, i.e., it inhibited proliferation of a leukemia cell line HL-60 with an $\mathrm{IC}_{50}$ value of $23.6 \mu \mathrm{M}$, while it inhibited proliferation of the epidermal cell line HeLa with an $\mathrm{IC}_{50}$ value of $54.6 \mu \mathrm{M} .^{1)}$

On the other hand, ICM0301A (3), which is a natural product isolated from the culture broth of Aspergillus sp. F1491 and structurally similar to FSA (1), has recently been reported to possess anti-angiogenic activity [the anti-angiogenic activity of ICM0301A (3) was assessed by using the in

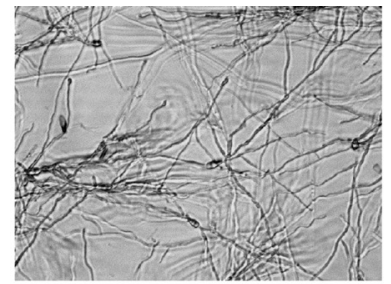

(a) control

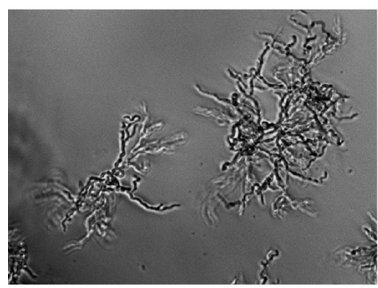

(d) Griseofulvin $50 \mu \mathrm{M}$

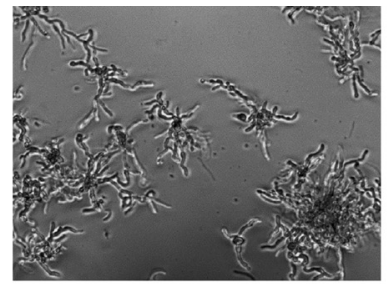

(b) FSA $25 \mu \mathrm{M}$

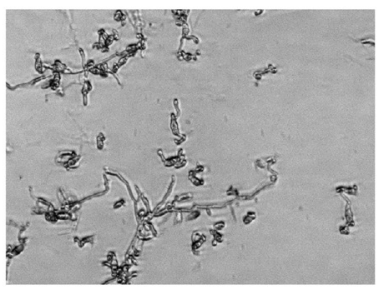

(e) Nocodazole $6.3 \mu \mathrm{M}$

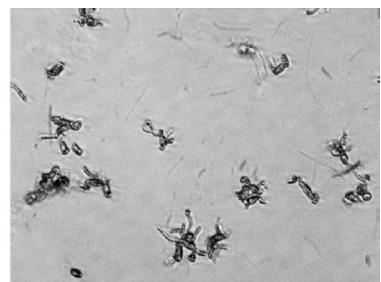

(c) Rhizoxin $0.63 \mu \mathrm{M}$

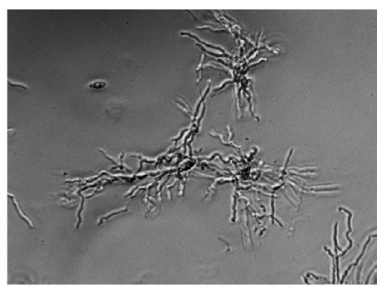

( f) Phomopsidin $25 \mu \mathrm{M}$

Fig. 1. Curling on Mycelia Germinated from Conidia of Pyricularia oryzae P-2b 
vitro angiogenesis model of culturing fragment of rat aorta in three-dimensional fibrin gels, and it is reported to show significant inhibitory activity of $52 \%$ inhibition at $1 \mu \mathrm{g} / \mathrm{ml}] .{ }^{9,10)}$ This reported result together with the above-mentioned findings prompted us to examine the effect of FSA (1) on the growth and tube formation of human umbilical vein endothelial cells (HUVEC).

Here, we describe the anti-angiogenic activity of FSA (1) in HUVEC tube formation assay, a preliminary study of the structure-activity relationship, an analysis of the cellular uptake and distribution of FSA (1) with biosynthetically prepared ${ }^{3} \mathrm{H}$-labeled FSA (Fig. 7), and the preparation of an affinity-labeling agent, CAFSA (Coumarin- and Azidophenyl-substituted FSA derivative: 6, Fig. 9).

\section{Results and Discussion}

Large-Scale Preparation of FSA (1) To obtain a sufficient amount of FSA (1) for our studies, the culture conditions were optimized. Our previous studies indicated that the production of FSA (1) by Fusarium sp. K432 is temperaturedependent, i.e., FSA (1) was produced at $20^{\circ} \mathrm{C}$, but not at $27^{\circ} \mathrm{C}$. ${ }^{7)}$ Therefore, we investigated the time-course of FSA (1) production by the fungus in standing culture in a potato dextrose medium at $20^{\circ} \mathrm{C}$. Quantification of FSA (1) in the culture medium by means of HPLC indicated that the production of FSA (1) was time-dependent and saturated after
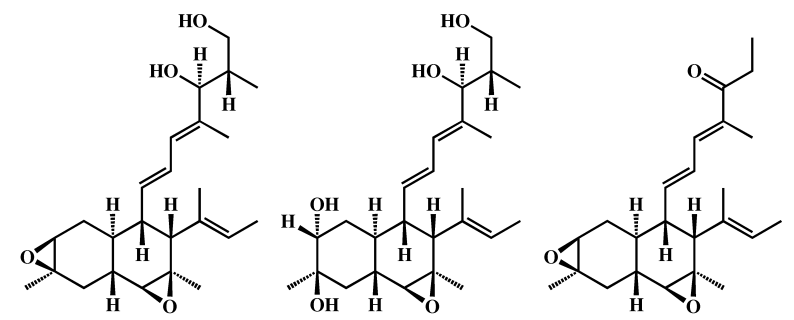

1: Fusarielin A (FSA)

2: Fusarielin B (FSB)

3: ICM0301A

Fig. 2. Structures of FSA (1), FSB (2) and ICM0301A (3)

a

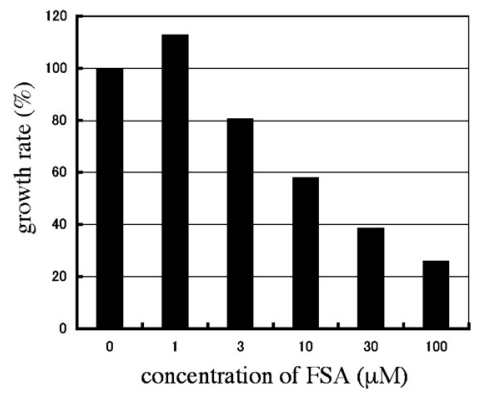

C

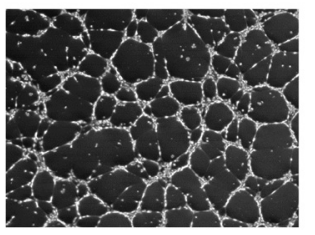

control
$21 \mathrm{~d}$. Based on the results, a total of 2.41 of culture was kept at $20^{\circ} \mathrm{C}$ for $21 \mathrm{~d}$, then the medium was extracted with a mixture of acetone and benzene. Successive column chromatographies using three types of resins gave $550 \mathrm{mg}$ of FSA (1) as a white powder (Fig. 3, see Experimental). The structure and purity of the isolated FSA (1) were confirmed by HPLC, NMR spectroscopy and mass spectrometry.

Growth-Inhibitory Activity and Anti-angiogenic Activity of FSA toward HUVEC Next, we investigated the growth-inhibitory activity of FSA (1) on HUVEC. FSA (1) inhibited the growth of HUVEC with the $\mathrm{IC}_{50}$ value of $19.3 \mu \mathrm{M}$ after $72 \mathrm{~h}$ incubation, which is in good accordance with the $\mathrm{IC}_{50}$ value for HL-60 cells $\left(\mathrm{IC}_{50}=23.6 \mu \mathrm{M}\right)$ (Fig. $4 \mathrm{a}$, Table 1). Anti-angiogenic activity of FSA (1) was assessed by means of HUVEC tube formation assay. ${ }^{11)}$ FSA (1) exhibited moderate anti-angiogenic activity with the $\mathrm{IC}_{50}$ value of $7.1 \mu \mathrm{M}$ (Figs. 4b, c, Table 1).

In our previous studies, fusarielin B (2: FSB) (Fig. 2), in which one of the two epoxy groups of FSA (1) was opened, was co-isolated with FSA (1). FSB (2) did not induce curling of mycelia of $P$. oryzae P-2b, ${ }^{3)}$ suggesting that the two epoxy groups of FSA (1) are essential for the activity. On the other

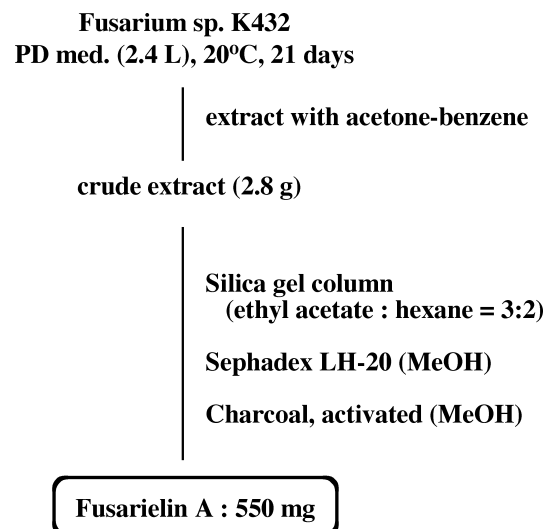

Fig. 3. Purification Scheme of FSA (1)

b
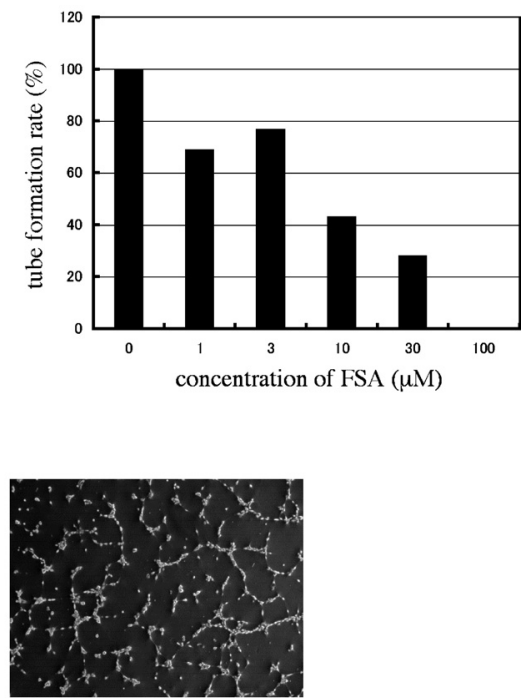

FSA $30 \mu \mathrm{M}$

Fig. 4. Effects of FSA (1) on HUVEC Growth and Tube Formation

(a) Growth inhibitory activity of FSA (1) toward HUVEC (incubated for $72 \mathrm{~h}$ ). (b) Tube formation inhibitory activity of FSA (1) toward HUVEC (treated for $6 \mathrm{~h}$ ). (c) Microscopic images of HUVEC cells treated with or without $30 \mu \mathrm{M}$ FSA for $6 \mathrm{~h}$ (see Experimental). 
Table 1. HL-60/HUVEC Cell Growth Inhibitory Activity and HUVEC Tube Formation Inhibitory Activity of FSA (1), 3-Bn-FSA (4) and 1,3-Bn 2 -FSA (5)

\begin{tabular}{|c|c|c|c|c|}
\hline & & FSA & 3-Bn-FSA & $1,3-\mathrm{Bn}_{2}-\mathrm{FSA}$ \\
\hline \multirow{4}{*}{ inhibitory activity } & HL-60 $\left(\mathrm{IC}_{50}: \mu \mathrm{M}\right)$ & 23.6 & 15.3 & 63.4 \\
\hline & $\operatorname{HUVEC}\left(\mathrm{IC}_{50}: \mu \mathrm{M}\right)$ & 19.3 & N.D. & $>100$ \\
\hline & HUVEC: after $72 \mathrm{~h}$ incubation at $100 \mu \mathrm{M}(\%)$ & 83 & 98 & 34 \\
\hline & HUVEC: after $6 \mathrm{~h}$ incubation at $100 \mu \mathrm{M}(\%)$ & 48 & 46 & 49 \\
\hline $\begin{array}{l}\text { HUVEC tube } \\
\text { formation inhibitory activity }\end{array}$ & HUVEC: after $6 \mathrm{~h}\left(\mathrm{IC}_{50}: \mu \mathrm{M}\right)$ & 7.1 & N.D. & N.D. \\
\hline
\end{tabular}

N.D. $=$ not determined.
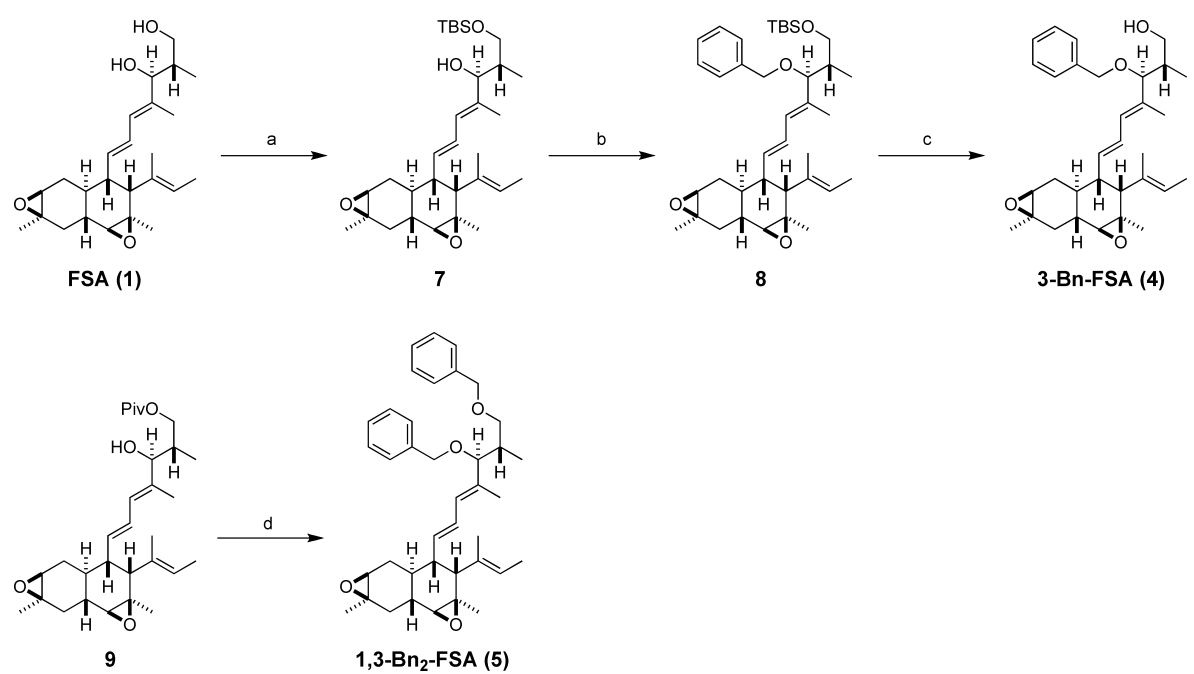

Fig. 5. Synthesis of 3-Bn-FSA (4) and 1,3-Bn - -FSA (5)

Reagents and conditions: (a) tert-butyldimethylchlorosilane, $\mathrm{Et}_{3} \mathrm{~N}, \mathrm{DMAP}, \mathrm{CH}_{2} \mathrm{Cl}_{2}$, r.t., $23 \mathrm{~h}(86 \%$ ); (b) BnBr, NaH, DMF, r.t., 20 h (39\%); (c) $0.13 \mathrm{M}$ tetra- $n$-butylammonium fluoride, THF solution, r.t., $25 \mathrm{~h}$ (89\%); (d) $\mathrm{BnBr}, \mathrm{NaH}$, THF, $45^{\circ} \mathrm{C}, 14 \mathrm{~h}(74 \%)$.

hand, it was not clear whether or not the two hydroxyl groups at positions 1 and 3 (numbering is shown in Fig. 7) are necessary for the activity. To obtain preliminary information about the structure-activity relationships of FSA (1), derivatives with one or two benzylated hydroxyl group(s) were prepared (Fig. 5), i.e., 3-Bn-FSA (4) in which the 3-secondary alcohol group is protected with a benzyl group and $1,3-\mathrm{Bn}_{2}-$ FSA (5) in which the 1-primary and 3-secondary alcohol groups are both protected with benzyl groups (Fig. 5). Because azido-functionalized benzyl group was successfully applied in identifying the molecular weight of target protein of dantrolene analog by Hosoya and co-workers, ${ }^{12)}$ we made a choice for the benzyl group not only to obtain preliminary information of SAR study of FSA (1), but also to determine the site of FSA (1) to introduce azido-functionalized benzyl group for a planned photoaffinity labeling (vide infra) ${ }^{12)}$ The structures of the synthesized compounds were confirmed by ${ }^{1} \mathrm{H}-\mathrm{NMR}$ spectroscopy and mass spectrometry.

The two derivatives, 3-Bn-FSA (4) and $1,3-\mathrm{Bn}_{2}$-FSA (5) (Fig. 5), were investigated for anti-angiogenic activity, growth-inhibitory activity against HUVEC/HL-60 cells (Table 1, Fig. 6A), and malformation-inducing activity towards mycelia of $P$. oryzae P-2b (Fig. 6B). 3-Bn-FSA (4) showed anti-angiogenic activity and growth-inhibitory activity against HUVEC/HL-60 with almost the same potency as FSA (1) (Table 1, Fig. 6A), but did not induce curling of mycelia [although growth-inhibitory activity against $P$. oryzae P-2b was observed (Fig. 6B)]. 1,3-Bn ${ }_{2}$-FSA (5) showed anti-angiogenic activity (Fig. 6A), but lacked growth-inhibitory activity against HUVEC/HL-60 cells. It did not show curling-inducing activity on mycelia or growthinhibitory activity against $P$. oryzae P-2b (Fig. 6B). The results suggest that (i) the free hydroxyl groups are critical for the curling-inducing activity towards mycelia germinated from conidia of $P$. oryzae $\mathrm{P}-2 \mathrm{~b}$, (ii) the free hydroxyl groups are not necessary for the anti-angiogenic activity, and (iii) the free hydroxyl groups at the 1-position and the 3-position are necessary and unnecessary, respectively, for the HUVEC/HL-60 cell growth-inhibitory activity. These findings indicate that it may be possible to separate each activity, i.e., cell growth inhibition, anti-angiogenic activity and curling-inducing activity, by the structural development of FSA (1). In other words, different structural features, especially the presence of the free hydroxyl groups, appear to be critically recognized by putative target molecules involved in the three biological activities.

Preparation of $\left[{ }^{3} \mathbf{H}\right]$ FSA As mentioned above, the antiangiogenic activity of FSA (1) seems to be specific, at least in part, and the cell growth-inhibitory activity elicited by FSA (1) seems to be cell type-selective. These results suggest that FSA (1) may elicit its biological activity by binding to a specific target molecule(s). To examine this working hypothesis, we planned to prepare ${ }^{3} \mathrm{H}$-labeled FSA $\left(\left[{ }^{3} \mathrm{H}\right] \mathrm{FSA}\right)$. FSA (1) is a decaketide, and previous experiments indicated the incorporation of both carbons of acetate and the methyl carbon of methionine (Fig. 7). ${ }^{7}$ To prepare $\left[{ }^{3} \mathrm{H}\right] \mathrm{FSA}$, we first 
[A]

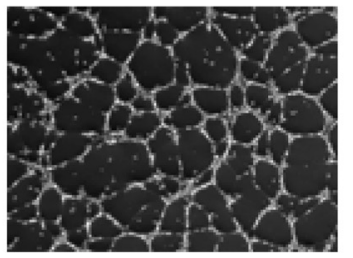

control

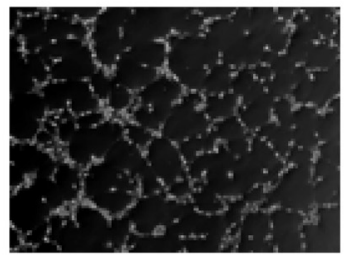

3-Bn-FSA

[B]

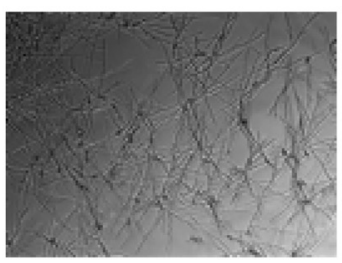

control

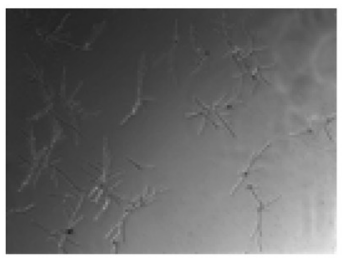

3-Bn-FSA

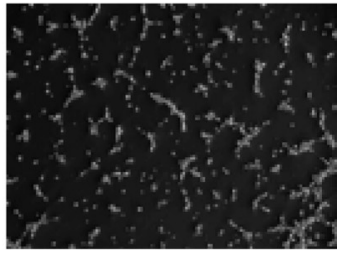

FSA

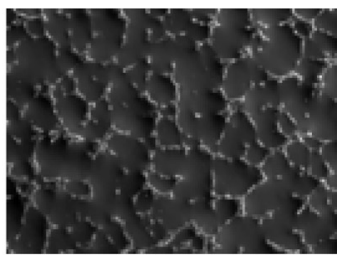

$1,3-\mathrm{Bn}_{2}-\mathrm{FSA}$

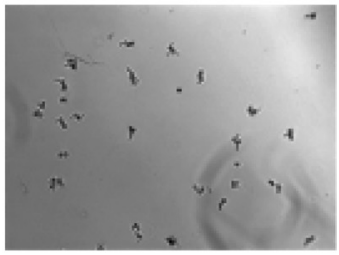

FSA

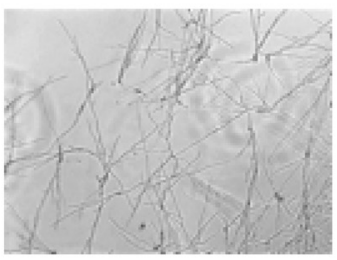

$1,3-\mathrm{Bn}_{2}-\mathrm{FSA}$

Fig. 6. Effects of FSA (1) and Its Benzylated Derivatives [3-Bn-FSA (4) and $1,3-\mathrm{Bn}_{2}$-FSA (5)] at $100 \mu \mathrm{M}$ on HUVEC Tube Formation (A) and Germination of Conidia of Pyricularia oryzae P-2b (B)

examined the incorporation of methionine- $d_{3}$, using cultures of the K432 strain. After standing culture for $21 \mathrm{~d}$, FSA (1) was extracted and its structure was confirmed by ${ }^{1} \mathrm{H}-\mathrm{NMR}$ and mass spectrometry. The results showed that methionine$d_{3}$ was incorporated into FSA (1). Therefore, to prepare $\left[{ }^{3} \mathrm{H}\right] \mathrm{FSA}$, we added L-methionine, [methyl- $\left.{ }^{3} \mathrm{H}\right](185 \mathrm{MBq})$ to a culture medium which had been pre-cultured for $6 \mathrm{~d}$. The culture was continued for a further $8 \mathrm{~d}$, then FSA (1) was extracted from the medium and purified by HPLC to give $\left[{ }^{3} \mathrm{H}\right] \mathrm{FSA}$ with the specific activity of $75 \mathrm{MBq} / \mathrm{mmol}$.

Distribution of $\left[{ }^{3} \mathbf{H}\right] \mathbf{F S A}$ in HL-60 Cells To examine the cellular uptake and distribution of FSA (1), we selected HL-60 cells because the HL-60 cell growth inhibition assay could discriminate FSA (1) and 3-Bn-FSA (4) [active] from $1,3-\mathrm{Bn}_{2}$-FSA (5) [inactive]. This raises the possibility of developing affinity-labeling agents using the 3-hydroxyl group as a functional group on which a photolabile group can be introduced (vide infra).

HL-60 cells were incubated for $20 \mathrm{~h}$ under $5 \% \mathrm{CO}_{2}$ at $37^{\circ} \mathrm{C}$ in the presence of $\left[{ }^{3} \mathrm{H}\right] \mathrm{FSA}(10 \mu \mathrm{M})$. After the incubation, the mixture was centrifuged at $2000 \mathrm{rpm}$ for $5 \mathrm{~min}$ at

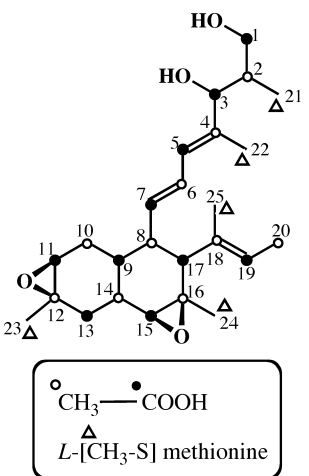

Fig. 7. Schematic Representation of Incorporation of Biosynthetic Precursors into FSA (1)

[A]

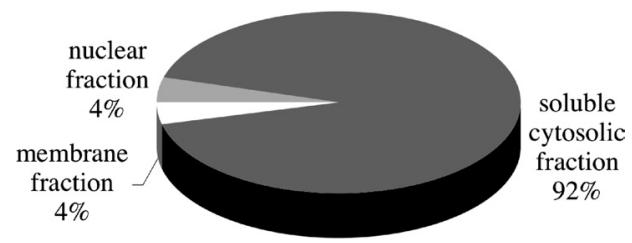

[B]

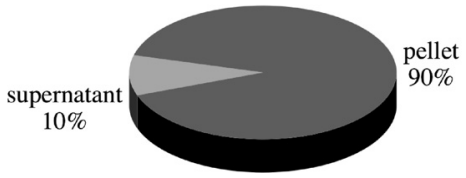

Fig. 8. Uptake and Distribution of $\left[{ }^{3} \mathrm{H}\right] \mathrm{FSA}$

[A] Distribution of $\left[{ }^{3} \mathrm{H}\right] \mathrm{FSA}$ in fractionated cell pellet. [B] Distribution of $\left[{ }^{3} \mathrm{H}\right] \mathrm{FSA}$ in ammonium sulfate precipitate of soluble cytosolic fraction.

$4{ }^{\circ} \mathrm{C}$ to separate the supernatant and cell pellet. The cell pellet contained about ten times higher concentration of radioactivity than the supernatant, suggesting efficient uptake of $\left[{ }^{3} \mathrm{H}\right] \mathrm{FSA}$ into the cells. Separation of subcellular fractions of HL-60 cells and the measurement of $\left[{ }^{3} \mathrm{H}\right] \mathrm{FSA}$ uptake were performed as described previously. ${ }^{13-15)}$ Briefly, HL-60 cells, which had been incubated with $\left[{ }^{3} \mathrm{H}\right] \mathrm{FSA}(10 \mu \mathrm{M})$, were lysed with hypotonic solution $(20 \mathrm{~mm}$ Tris- $\mathrm{HCl})$, and the nuclear fraction, soluble cytosolic fraction and membrane fraction were separated by successive centrifugation. Approximately $92 \%$ of $\left[{ }^{3} \mathrm{H}\right] \mathrm{FSA}$ was distributed to the soluble cytosolic fraction (Fig. 8A). Next, 90\% ammonium sulfate was added to the soluble cytosolic fraction, and the mixture was centrifuged to separate the supernatant and pellet. More than $90 \%$ of $\left[{ }^{3} \mathrm{H}\right] \mathrm{FSA}$ was found in the pellet, i.e., the salted-out protein fraction (Fig. 8B). Therefore, FSA (1) might have been bound to specific protein(s) existing in the soluble cytosolic fraction.

Photoaffinity Label Based on the above results, we designed a photoaffinity probe to detect the putative target molecule(s) of FSA (1) in HL-60 cells. As the free hydroxyl group at the 3-position of FSA (1) was considered to be unnecessary for cell growth-inhibitory activity toward HL-60 cells, we designed and synthesized an FSA derivative with a 

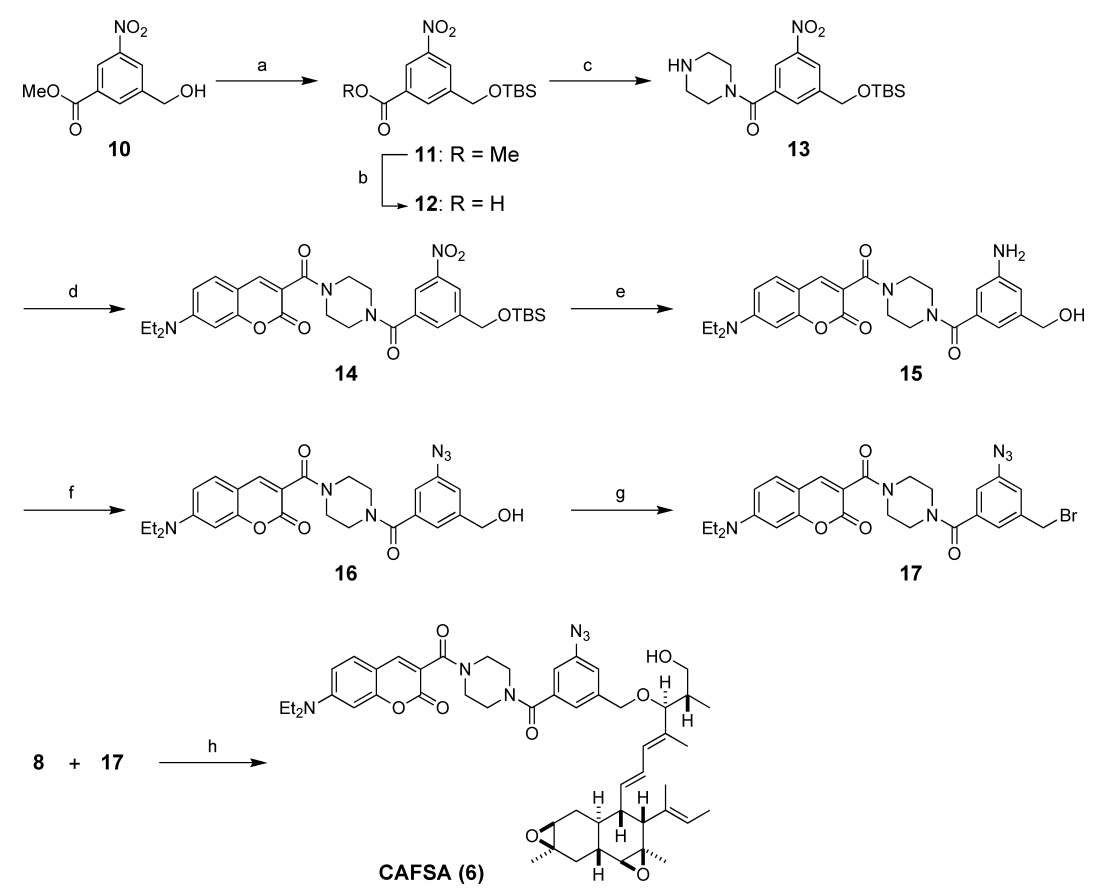

Fig. 9. Synthesis of Photoaffinity Labeling Agent, CAFSA (6)

Reagents and conditions: (a) tert-butyldimethylchlorosilane, $\mathrm{Et}_{3} \mathrm{~N}, \mathrm{DMAP}, \mathrm{CH}_{2} \mathrm{Cl}_{2}$, r.t., $18 \mathrm{~h}\left(98 \%\right.$ ); (b) $2 \mathrm{~N} \mathrm{NaOH}$ aq., THF-MeOH, r.t., 3.5 h; (c) piperazine, $1,1^{\prime}$-carbonyl diimidazole, DMF, r.t., $15 \mathrm{~h}\left(82 \%, 2\right.$ steps); (d) 7-diethylaminocoumarin-2-carboxylic acid, $1,1^{\prime}$-carbonyldiimidazole, $\mathrm{DMF}$, r.t., $19 \mathrm{~h}(84 \%) ;\left(\right.$ e) $\mathrm{SnCl}{ }_{2} \cdot 2 \mathrm{H}_{2} \mathrm{O}, \mathrm{EtOAc}, 90^{\circ} \mathrm{C}, 7 \mathrm{~h}$ (98\%); (f) $\mathrm{NaNO}_{2}, \mathrm{NaN}_{3}, 4 \mathrm{~N} \mathrm{HCl}, 0{ }^{\circ} \mathrm{C}, 20 \mathrm{~min}$ (93\%); (g) $\mathrm{CBr}_{4}, \mathrm{P}\left(n\right.$-octyl) $3, \mathrm{CH}_{2} \mathrm{Cl}_{2}$, r.t., $3 \mathrm{~h}$ (59\%); (h) sodium hexamethyldisilazide (NaHMDS), DMF, r.t., 24 h (12\%).

fluorescent and photoreactive group(s) at the 3-secondary alcohol group, i.e., an FSA derivative bearing a coumarin and an azidophenyl group (6: CAFSA, Fig. 9). The coumarin skeleton was chosen as a fluorescent chromophore, and an azidophenyl moiety was introduced as the photoreactive part. ${ }^{16-18)}$ The probe CAFSA (6) was synthesized as shown in Fig. 9.

A preliminary photoaffinity labeling experiment using CAFSA (6) was performed (Fig. 10) with the soluble cytosolic fraction of cultured HL-60 cells, using a method similar to that described previously. ${ }^{19-21)}$ The HL-60 cell extract was incubated with CAFSA (6) [bars $(a-c)$ in Fig. 10] in the presence [bar (b) in Fig. 10] or absence [bars (a) and (c) in Fig. 10] of an excess amount of FSA (1), and then the mixture was irradiated at $254 \mathrm{~nm}$ with a compact UV lamp (UVP, $4 \mathrm{~W})$. The irradiated mixture was subjected to gel filtration column chromatography to obtain the macromolecular (protein) fraction, and the fluorescence intensity of this fraction was measured (relative fluorescence intensity is indicated by the length of the bars in Fig. 10). As shown in Fig. 10, the macromolecular fraction and non-reacted CAFSA (6) were efficiently separated by the gel filtration column chromatography [bars (c) and (d) in Fig. 10]. The high and low levels of relative fluorescence intensity shown by the bars (a) and (c) in Fig. 10, respectively, indicate that the covalent binding of CAFSA (6) to the macromolecular fraction occurred irradiation-dependently. The covalent binding of CAFSA (6) was inhibited in the presence of an excess of FSA (1) (compare bars (a) and (b) in Fig. 10), suggesting that CAFSA (6) binds specifically at the FSA (1) binding site(s). These results suggest that CAFSA (6) is a suitable photoaffinity labeling agent to identify the target molecule(s) of FSA (1).

Further work to identify the macromolecule(s) photoaffinity-labeled with CAFSA (6) is under way.

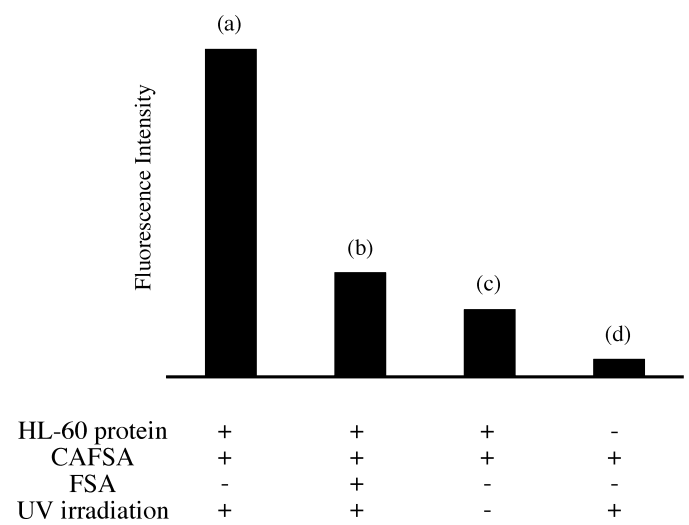

Fig. 10. Results of Photoaffinity Labeling Experiments

\section{Experimental}

Large-Scale Purification of FSA (1) Fusarium sp. K432 strain was cultured in dishes each containing $30 \mathrm{ml}$ of potato dextrose medium (potato $200 \mathrm{~g}$, dextrose $20 \mathrm{~g}$ per liter of water) at $20^{\circ} \mathrm{C}$ for $21 \mathrm{~d}$. The acetone-benzene extract of a total of 2.41 of culture was separated by silica gel column chromatography. The column was eluted with ethyl acetate-hexane $(3: 2)$. The solution was concentrated, and the residue $(2.8 \mathrm{~g})$ was subjected to Sephadex LH-20 column chromatography. The column was eluted with $\mathrm{MeOH}$. The solution was concentrated, and the residue was applied to a column of activated charcoal. The column was eluted with $\mathrm{MeOH}$, and the eluate was concentrated to give FSA (1) as a white powder $(550 \mathrm{mg})$.

Cell Culture HL-60 cells were cultured in RPMI1640 medium supplemented with $10 \%$ heat-inactivated fetal bovine serum (FBS; Gibco BRL) at $37^{\circ} \mathrm{C}$ under a $5 \% \mathrm{CO}_{2}$ atmosphere. HUVECs were cultured in EBM-2 medium supplemented with growth factors (hEGF, VEGF, hFGF-B, and R3IGF-1, as well as FBS) at $37^{\circ} \mathrm{C}$ under a $5 \% \mathrm{CO}_{2}$ atmosphere.

Growth Inhibitory Activity against HUVEC and HL-60 Each cell was placed in 12-well plates and treated with various concentrations of the test compounds at $37^{\circ} \mathrm{C}$ for 6 or $72 \mathrm{~h}$. After the incubation, the viability of the treated cells was measured by direct counting under a microscope.

HUVEC Tube Formation Assay HUVECs were plated on Matrigel and cultured in the presence of test compounds for $6 \mathrm{~h}$, then tube formation 
was measured as previously reported. ${ }^{11)}$ Briefly, six-well plates were coated with $1.5 \mathrm{ml}$ of the Matrigel basement membrane matrix (Becton Dickinson) and allowed to gel at $37^{\circ} \mathrm{C}$ under a $5 \% \mathrm{CO}_{2}$ atmosphere for $30 \mathrm{~min}$. Then, HUVECs were plated at $5.0 \times 10^{5}$ cells/well in Dulbecco's modified Eagle medium (DMEM) containing the vehicle $(0.5 \%$ DMSO) in the presence or absence of various concentrations of the test compound, and incubation was continued at $37^{\circ} \mathrm{C}$ under a $5 \% \mathrm{CO}_{2}$ atmosphere for $6 \mathrm{~h}$. Each well was photographed using a $\times 100$ objective to analyze tube formation. The corresponding area was evaluated as the number of pixels using MetaMorph software (Universal Imaging, Downingtown, PA, U.S.A.).

Curling of Mycelia of $\boldsymbol{P}$. oryzae $\boldsymbol{P}-2 \boldsymbol{b}$ Conidia of $P$. oryzae $\mathrm{P}-2 \mathrm{~b}$ germinated at $27^{\circ} \mathrm{C}$ in water suspension containing $0.02 \%$ yeast extract and were easily observed under an optical microscope. A time point of $16 \mathrm{~h}$ was the most appropriate for observation of hyphal growth. ${ }^{8)}$

Preparation of $\left[{ }^{3} \mathbf{H}\right]$ FSA L-Methionine, [methyl $\left.-{ }^{3} \mathrm{H}\right](185 \mathrm{MBq})$ in $\mathrm{EtOH}$ was left on a dish for several days. After the EtOH had completely evaporated, $6 \mathrm{~d}$ culture of the K432 strain was added to the dish. After a further $8 \mathrm{~d}$, the culture was extracted with acetone-benzene. The organic solution was evaporated, and the residue was purified and subjected to HPLC. The yield of $\left[{ }^{3} \mathrm{H}\right] \mathrm{FSA}$ was $33.6 \mu \mathrm{g}$, and the specific activity was $75 \mathrm{MBq} / \mathrm{mmol}$.

Distribution of $\left[{ }^{3} \mathbf{H}\right]$ FSA in HL-60 Cells HL-60 cells were incubated in RPMI1640 medium in the presence or absence of $\left[{ }^{3} \mathrm{H}\right]$ FSA $(10 \mu \mathrm{M})$ for $20 \mathrm{~h}$. Treated HL-60 cells were centrifuged at $2000 \mathrm{rpm}$ for $5 \mathrm{~min}$ at $4{ }^{\circ} \mathrm{C}$. The radioactivity of the supernatant was measured. The pellet was resuspended in buffer $(20 \mathrm{~mm}$ Tris- $\mathrm{HCl}, 0.6 \mathrm{M} \mathrm{KCl})$, and centrifuged at $2000 \mathrm{rpm}$ for $5 \mathrm{~min}$ at $4{ }^{\circ} \mathrm{C}$. The radioactivity of the resulting pellet was measured.

HL-60 cells were incubated in RPMI1640 medium in the presence or absence of $\left[{ }^{3} \mathrm{H}\right] \mathrm{FSA}(10 \mu \mathrm{M})$ for $20 \mathrm{~h}$. Treated HL-60 cells were centrifuged at $2000 \mathrm{rpm}$ for $5 \mathrm{~min}$ at $4{ }^{\circ} \mathrm{C}$. The pellet was resuspended in buffer, and centrifuged at $2000 \mathrm{rpm}$ for $5 \mathrm{~min}$ at $4{ }^{\circ} \mathrm{C}$. The pellet was resuspended in hypotonic solution ( $20 \mathrm{~mm}$ Tris- $\mathrm{HCl})$, vortexed if necessary, and kept on ice for $45 \mathrm{~min}$. After microscopic confirmation of cell lysis, the suspension was centrifuged at $2500 \mathrm{rpm}$ for $15 \mathrm{~min}$ at $4{ }^{\circ} \mathrm{C}$. The pellet was resuspended in buffer and centrifuged at $2500 \mathrm{rpm}$ for $15 \mathrm{~min}$ at $4{ }^{\circ} \mathrm{C}$. The resulting pellet was designated as the nuclear fraction. The supernatant was centrifuged at $50000 \mathrm{rpm}$ for $1 \mathrm{~h}$ at $4{ }^{\circ} \mathrm{C}$. The resulting supernatant was designated as the soluble cytosolic fraction, and the pellet was designated as the membrane fraction. The radioactivity of each fraction was measured with a liquid scintillation counter.

Derivatives of FSA. General ${ }^{1} \mathrm{H}-\mathrm{NMR} \quad(500 \mathrm{MHz})$ spectra was recorded on a JEOL JNM- $\alpha 500$ spectrometer. Mass spectra were obtained on JEOL JMA-HX 110 spectrometer with $m$-nitrobenzyl alcohol. Melting points were determined on Yanaco MP-J3 micro melting point apparatus, and are uncorrected. Flash column chromatography was performed on silica gel 60 (Kanto Kagaku, 40-100 $\mu \mathrm{m}$ ).

1-(tert-Butyldimethylsilyloxy)-FSA (7) To a solution of FSA (1) $(58.6 \mathrm{mg}, 0.146 \mathrm{mmol})$ in $\mathrm{CH}_{2} \mathrm{Cl}_{2}(0.4 \mathrm{ml})$ were added tert-butyldimethylchlorosilane $(24.0 \mathrm{mg}, 0.159 \mathrm{mmol})$, triethylamine $(25.0 \mu \mathrm{l}, 0.179 \mathrm{mmol})$, and $N, N$-dimethylaminopyridine $(1.0 \mathrm{mg}, 0.008 \mathrm{mmol})$. The mixture was stirred at ambient temperature for $23 \mathrm{~h}$, then applied directly to silica-gel and purified by silica-gel column chromatography (hexane/ethyl acetate $=$ $7 / 1$, then $4 / 1)$ to give 1-(tert-butyldimethylsilyloxy)-FSA (7) (64.3 mg, $0.124 \mathrm{mmol}, 86 \%)$ as a pale-yellow oil; ${ }^{1} \mathrm{H}-\mathrm{NMR}\left(\mathrm{DMSO}-d_{6}\right) \delta: 0.00(3 \mathrm{H}$ s), $0.01(3 \mathrm{H}, \mathrm{s}), 0.69(3 \mathrm{H}, \mathrm{d}, J=7.0 \mathrm{~Hz}), 0.85(9 \mathrm{H}, \mathrm{s}), 0.92-1.00(1 \mathrm{H}, \mathrm{m})$, $1.11(3 \mathrm{H}, \mathrm{s}), 1.19-1.28(1 \mathrm{H}, \mathrm{m}), 1.27(3 \mathrm{H}, \mathrm{s}), 1.47(1 \mathrm{H}, \mathrm{ddd}, J=3.0,10.5$, $14.0 \mathrm{~Hz}), 1.54-1.75(6 \mathrm{H}, \mathrm{m}), 1.59(3 \mathrm{H}, \mathrm{s}), 1.61(3 \mathrm{H}, \mathrm{s}), 2.02-2.14(1 \mathrm{H}$, m), $2.06(1 \mathrm{H}, \mathrm{dd}, J=3.0,14.0 \mathrm{~Hz}), 2.43-2.52(1 \mathrm{H}, \mathrm{m}), 2.70(1 \mathrm{H}, \mathrm{s}), 2.90$ $(1 \mathrm{H}, \mathrm{d}, J=5.5 \mathrm{~Hz}), 3.43(1 \mathrm{H}, \mathrm{dd}, J=7.0,9.5 \mathrm{~Hz}), 3.61(1 \mathrm{H}, \mathrm{dd}, J=4.0$, $8.5 \mathrm{~Hz}), 3.70(1 \mathrm{H}, \mathrm{dd}, J=4.0,9.5 \mathrm{~Hz}), 4.62(1 \mathrm{H}, \mathrm{d}, J=4.0 \mathrm{~Hz}), 5.13(1 \mathrm{H}, \mathrm{dd}$, $J=10.5,15.0 \mathrm{~Hz}), 5.13-5.20(1 \mathrm{H}, \mathrm{m}), 5.79(1 \mathrm{H}, \mathrm{d}, J=10.5 \mathrm{~Hz}), 6.13-6.24$ $(1 \mathrm{H}, \mathrm{m})$. MS (FAB): $m / z 539(\mathrm{M}+\mathrm{Na})^{+}$.

1-(tert-Butyldimethylsilyl)-3-Bn-FSA (8) To a solution of $7(28.9 \mathrm{mg}$, $0.056 \mathrm{mmol})$ in DMF $(0.4 \mathrm{ml})$ was added $\mathrm{NaH}(55-72 \%$ contained, $2.3 \mathrm{mg})$. After $10 \mathrm{~min}$, to this was added benzyl bromide $(15.0 \mu \mathrm{l}, 0.126 \mathrm{mmol})$, and the mixture was stirred at ambient temperature for $16 \mathrm{~h}$. Further $\mathrm{NaH}(55-$ $72 \%$ contained, $2.3 \mathrm{mg}$ ) and benzyl bromide $(15.0 \mu \mathrm{l}, 0.126 \mathrm{mmol})$ were added and the mixture was stirred at the same temperature for $4 \mathrm{~h}$. The reaction was quenched by adding $\mathrm{H}_{2} \mathrm{O}$ and the mixture was extracted with hexane. The product was purified by silica-gel column chromatography (hexane/ethyl acetate $=19 / 1$, then 9/1) to give 1-(tert-butyldimethylsilyloxy)3-Bn-FSA (8) $(13.1 \mathrm{mg}, 0.022 \mathrm{mmol}, 39 \%)$ as a colorless oil; ${ }^{1} \mathrm{H}-\mathrm{NMR}$ $\left(\mathrm{DMSO}-d_{6}\right) \delta$ : $-0.01(6 \mathrm{H}, \mathrm{s}), 0.70(3 \mathrm{H}, \mathrm{d}, J=7.0 \mathrm{~Hz}), 0.85(9 \mathrm{H}, \mathrm{s}), 1.01$ $(1 \mathrm{H}, \mathrm{dd}, J=11.0,15.0 \mathrm{~Hz}), 1.12(3 \mathrm{H}, \mathrm{s}), 1.20-1.25(1 \mathrm{H}, \mathrm{m}), 1.26(3 \mathrm{H}, \mathrm{s})$,
$1.49(1 \mathrm{H}, \mathrm{ddd}, J=3.0,10.0,14.0 \mathrm{~Hz}), 1.56-1.68(4 \mathrm{H}, \mathrm{m}), 1.59(3 \mathrm{H}, \mathrm{s}), 1.62$ $(3 \mathrm{H}, \mathrm{s}), 1.72-1.82(2 \mathrm{H}, \mathrm{m}), 2.06-2.18(1 \mathrm{H}, \mathrm{m}), 2.07(1 \mathrm{H}, \mathrm{dd}, J=3.0$, $14.0 \mathrm{~Hz}), 2.44-2.49(1 \mathrm{H}, \mathrm{m}), 2.72(1 \mathrm{H}, \mathrm{s}), 2.93(1 \mathrm{H}, \mathrm{d}, J=6.0 \mathrm{~Hz}), 3.50$ $(1 \mathrm{H}, \mathrm{d}, J=9.0 \mathrm{~Hz}), 3.56(1 \mathrm{H}, \mathrm{td}, J=6.0,9.0 \mathrm{~Hz}), 3.68(1 \mathrm{H}, \mathrm{dd}, J=3.0$, $10.5 \mathrm{~Hz}), 4.18(1 \mathrm{H}, \mathrm{d}, J=11.5 \mathrm{~Hz}), 4.32(1 \mathrm{H}, \mathrm{d}, J=11.5 \mathrm{~Hz}), 5.13-5.20$ $(1 \mathrm{H}, \mathrm{m}), 5.21(1 \mathrm{H}, \mathrm{dd}, J=10.5,15.0 \mathrm{~Hz}), 5.88(1 \mathrm{H}, \mathrm{d}, J=11.0 \mathrm{~Hz}), 6.18$ $6.34(1 \mathrm{H}, \mathrm{m}), 7.23-7.34(5 \mathrm{H}, \mathrm{m})$. MS (FAB): $m / z 606(\mathrm{M})^{+}$

3-Bn-FSA (4) A mixture of $\mathbf{8}(13.0 \mathrm{mg}, 0.021 \mathrm{mmol})$ and tetra- $n$-butylammonium fluoride $(0.13 \mathrm{M}$ THF solution, $0.46 \mathrm{ml}, 0.06 \mathrm{mmol})$ was stirred at ambient temperature for overnight. The reaction mixture was applied directly to silica-gel and purified by silica-gel column chromatography (hexane/ethyl acetate $=3 / 1$ ) to give 3-Bn-FSA (4) $(9.4 \mathrm{mg}, 0.019 \mathrm{mmol}$, $89 \%$ ) as a colorless oil; ${ }^{1} \mathrm{H}-\mathrm{NMR}\left(\mathrm{DMSO}-d_{6}, 50{ }^{\circ} \mathrm{C}\right) \delta: 0.70(3 \mathrm{H}, \mathrm{d}$, $J=7.5 \mathrm{~Hz}), 1.13(3 \mathrm{H}, \mathrm{s}), 1.18-1.29(1 \mathrm{H}, \mathrm{m}), 1.27(3 \mathrm{H}, \mathrm{s}), 1.51(1 \mathrm{H}$, ddd, $J=3.0,10.0,14.0 \mathrm{~Hz}), 1.56-1.67(5 \mathrm{H}, \mathrm{m}), 1.60(3 \mathrm{H}, \mathrm{s}), 1.63(3 \mathrm{H}, \mathrm{s})$, $1.68-1.83(2 \mathrm{H}, \mathrm{m}), 2.08(1 \mathrm{H}, \mathrm{dd}, J=3.0,14.0 \mathrm{~Hz}), 2.14(1 \mathrm{H}$, ddd, $J=5.0$, $10.0,10.0 \mathrm{~Hz}), 2.44-2.51(1 \mathrm{H}, \mathrm{m}), 2.71(1 \mathrm{H}, \mathrm{s}), 2.93(1 \mathrm{H}, \mathrm{d}, J=5.0 \mathrm{~Hz})$, $3.33(1 \mathrm{H}, \mathrm{td}, J=6.5,10.0 \mathrm{~Hz}), 3.49(1 \mathrm{H}, \mathrm{d}, J=9.0 \mathrm{~Hz}), 3.61(1 \mathrm{H}, \mathrm{td}, J=4.5$, $10.5 \mathrm{~Hz}), 4.165(1 \mathrm{H}, \mathrm{t}, J=5.0 \mathrm{~Hz}), 4.166(1 \mathrm{H}, \mathrm{d}, J=12.0 \mathrm{~Hz}), 4.31(1 \mathrm{H}, \mathrm{d}$, $J=12.0 \mathrm{~Hz}), 5.14-5.24(1 \mathrm{H}, \mathrm{m}), 5.21(1 \mathrm{H}, \mathrm{dd}, J=10.0,15.0 \mathrm{~Hz}), 5.89(1 \mathrm{H}$, d, $J=11.0 \mathrm{~Hz}), 6.26(1 \mathrm{H}, \mathrm{dd}, J=11.0,15.0 \mathrm{~Hz}), 7.22-7.35(5 \mathrm{H}, \mathrm{m})$. HR-MS $\left(\mathrm{FAB},[\mathrm{M}-\mathrm{H}]^{+}\right.$) Calcd for $\mathrm{C}_{32} \mathrm{H}_{43} \mathrm{O}_{4}: 491.3161$, Found: 491.3206 .

1,3-Bn - -FSA (5) To a solution of 1-pivaloyloxy-FSA (9) ${ }^{7)}(27.9 \mathrm{mg}$, $0.057 \mathrm{mmol})$ in DMF $(0.4 \mathrm{ml})$ was added $\mathrm{NaH}(55-72 \%$ contained, $2.3 \mathrm{mg})$. After $30 \mathrm{~min}$, to this was added benzyl bromide $(15.0 \mu \mathrm{l}, 0.126 \mathrm{mmol})$ and the mixture was stirred at $40^{\circ} \mathrm{C}$ for $2 \mathrm{~h}$. Further $\mathrm{NaH}(55-72 \%$ contained, $4.6 \mathrm{mg}$ ) was then added and the mixture was stirred at the same temperature for $15 \mathrm{~h}$. The reaction was quenched by adding $\mathrm{H}_{2} \mathrm{O}$ and the mixture was extracted with hexane. The product was purified by silica-gel column chromatography (hexane/ethyl acetate $=10 / 1$, then $6 / 1$ ) to give $1,3-\mathrm{Bn}_{2}-\mathrm{FSA}(5)$ (24.6 mg, $0.042 \mathrm{mmol}, 74 \%$ ) as a colorless oil; ${ }^{1} \mathrm{H}-\mathrm{NMR}$ (DMSO- $d_{6}$ ) $\delta: 0.75$ $(3 \mathrm{H}, \mathrm{d}, J=7.0 \mathrm{~Hz}), 1.01(1 \mathrm{H}, \mathrm{dd}, J=7.0,9.5 \mathrm{~Hz}), 1.12(3 \mathrm{H}, \mathrm{s}), 1.26(3 \mathrm{H}, \mathrm{s})$, $1.49(1 \mathrm{H}$, ddd, $J=3.5,10.5,15.0 \mathrm{~Hz}), 1.59(3 \mathrm{H}, \mathrm{s}), 1.59-1.67(5 \mathrm{H}, \mathrm{m}), 1.64$ $(3 \mathrm{H}, \mathrm{s}), 1.76(1 \mathrm{H}, \mathrm{td}, J=5.0,15.0 \mathrm{~Hz}), 1.86-1.95(1 \mathrm{H}, \mathrm{m}), 2.07(1 \mathrm{H}, \mathrm{dd}$, $J=3.0,13.5 \mathrm{~Hz}), 2.07-2.17(1 \mathrm{H}, \mathrm{m}), 2.39-2.55(1 \mathrm{H}, \mathrm{m}), 2.72(1 \mathrm{H}, \mathrm{s})$ $2.93(1 \mathrm{H}, \mathrm{d}, J=6.5 \mathrm{~Hz}), 3.41(1 \mathrm{H}, \mathrm{dd}, J=6.5,9.0 \mathrm{~Hz}), 3.53(1 \mathrm{H}, \mathrm{d}$, $J=9.5 \mathrm{~Hz}), 3.55(1 \mathrm{H}, \mathrm{dd}, J=3.0,9.0 \mathrm{~Hz}), 4.12(1 \mathrm{H}, \mathrm{d}, J=12.0 \mathrm{~Hz}), 4.31(1 \mathrm{H}$ d, $J=12.0 \mathrm{~Hz}), 4.39(1 \mathrm{H}, \mathrm{d}, J=12.0 \mathrm{~Hz}), 4.44(1 \mathrm{H}, \mathrm{d}, J=12.0 \mathrm{~Hz}), 5.12-$ $5.23(1 \mathrm{H}, \mathrm{m}), 5.21(1 \mathrm{H}, \mathrm{dd}, J=9.5,15.0 \mathrm{~Hz}), 5.90(1 \mathrm{H}, \mathrm{d}, J=10.5 \mathrm{~Hz})$, $6.18-6.33(1 \mathrm{H}, \mathrm{m}), 7.16-7.36(10 \mathrm{H}, \mathrm{m})$. HR-MS [FAB, $(\mathrm{M})^{+}$] Calcd for $\mathrm{C}_{39} \mathrm{H}_{50} \mathrm{O}_{4}: 582.3709$, Found: 582.3679 .

Methyl 3-(tert-Butyldimethylsilyloxymethyl)-5-nitrobenzoate (11) To a solution of methyl 3-(hydroxymethyl)-5-nitrobenzoate $(\mathbf{1 0})^{16,17)}(422 \mathrm{mg}$, $2.00 \mathrm{mmol})$ in $\mathrm{CH}_{2} \mathrm{Cl}_{2}(5.0 \mathrm{ml})$ were added tert-butyldimethylchlorosilane $(330 \mathrm{mg}, 2.19 \mathrm{mmol})$, triethylamine $(340 \mu \mathrm{l}, 2.44 \mathrm{mmol})$ and $N, N$-dimethylaminopyridine $(10.0 \mathrm{ml}, 137 \mathrm{mmol})$, and the mixture was stirred at ambient temperature for $18 \mathrm{~h}$. The reaction was quenched by adding $\mathrm{H}_{2} \mathrm{O}$ and the mixture was extracted with ethyl acetate. The product was purified by silicagel column chromatography (hexane/ethyl acetate $=7 / 1$ ) to give methyl 3-(tert-butyldimethylsilyloxymethyl)-5-nitrobenzoate (11) (636 mg, $1.96 \mathrm{mmol}, 98 \%)$ as a white foram; ${ }^{1} \mathrm{H}-\mathrm{NMR}\left(\mathrm{CDCl}_{3}\right) \delta: 0.12(6 \mathrm{H}, \mathrm{s}), 0.95$ $(9 \mathrm{H}, \mathrm{s}), 3.96(3 \mathrm{H}, \mathrm{s}), 4.84(2 \mathrm{H}, \mathrm{s}), 8.25-8.31(1 \mathrm{H}, \mathrm{m}), 8.36-8.42(1 \mathrm{H}, \mathrm{m})$, $8.69-8.75(1 \mathrm{H}, \mathrm{m})$. MS (FAB): $m / z 326(\mathrm{M}+\mathrm{H})^{+}$

3-(tert-Butyldimethylsilyloxymethyl)-5-nitrobenzoic Acid (12) To a solution of $11(632 \mathrm{mg}, 1.94 \mathrm{mmol})$ in THF $(5.0 \mathrm{ml})$ and $\mathrm{H}_{2} \mathrm{O}(2.5 \mathrm{ml})$ was added $2 \mathrm{~N}$ aqueous $\mathrm{NaOH}(1.1 \mathrm{ml}, 2.20 \mathrm{mmol})$ and the mixture was stirred at ambient temperature for $3.5 \mathrm{~h}$. Evaporation under reduced pressure afforded an aqueous residue which was acidified with $2 \mathrm{~N} \mathrm{HCl}(c a . \mathrm{pH} 2)$ and extracted with ethyl acetate. The organic solution was washed with brine, dried $\left(\mathrm{MgSO}_{4}\right)$, and concentrated under reduced pressure to give 3-(tert-butyldimethylsilyloxymethyl)-5-nitrobenzoic acid (12) (583 mg, $1.87 \mathrm{mmol}, 96 \%)$ as a white solid which was used without further purification; ${ }^{1} \mathrm{H}-\mathrm{NMR}$ $\left(\mathrm{CDCl}_{3}\right) \delta: 0.14(6 \mathrm{H}, \mathrm{s}), 0.96(9 \mathrm{H}, \mathrm{s}), 4.87(2 \mathrm{H}, \mathrm{s}), 8.35(1 \mathrm{H}, \mathrm{s}), 8.44(1 \mathrm{H}$, s), $8.80(1 \mathrm{H}, \mathrm{s})$

3-(tert-Butyldimethylsilyloxymethyl)-5-nitrobenzoyl Piperazine (13) To a solution of $\mathbf{1 2}(581 \mathrm{mg}, 1.87 \mathrm{mmol})$ in DMF $(6.0 \mathrm{ml})$ was added $1,1^{\prime}$-carbonylbis- $1 H$-imidazole $(366 \mathrm{mg}, 2.26 \mathrm{mmol})$ and the mixture was stirred at ambient temperature for $40 \mathrm{~min}$. To this was added piperazine $(483 \mathrm{mg}, 5.61 \mathrm{mmol})$ and the mixture was stirred at the same temperature for $15 \mathrm{~h}$. The reaction was quenched by adding $\mathrm{H}_{2} \mathrm{O}$ and the mixture was extracted with ether, dried $\left(\mathrm{MgSO}_{4}\right)$, and concentrated under reduced pressure. The product was purified by silica-gel column chromatography $\left(\mathrm{CH}_{2} \mathrm{Cl}_{2} /\right.$ methanol=19/1) to give 3-(tert-butyldimethylsilyloxymethyl)-5-nitrobenzoyl piperazine $(\mathbf{1 3})(603 \mathrm{mg}, 1.59 \mathrm{mmol}, 85 \%)$ as a pale-yellow solid 
mp 91-93 ${ }^{\circ} \mathrm{C} .{ }^{1} \mathrm{H}-\mathrm{NMR}\left(\mathrm{CDCl}_{3}\right) \delta: 0.13(6 \mathrm{H}, \mathrm{s}), 0.95(9 \mathrm{H}, \mathrm{s}), 2.83(2 \mathrm{H}, \mathrm{br}$ s), $2.97(2 \mathrm{H}, \mathrm{br} \mathrm{s}), 3.38(2 \mathrm{H}, \mathrm{br} \mathrm{s}), 3.78(2 \mathrm{H}, \mathrm{br} \mathrm{s}), 4.83(2 \mathrm{H}, \mathrm{s}), 7.69(1 \mathrm{H}, \mathrm{s})$, $8.13(1 \mathrm{H}, \mathrm{s}), 8.23(1 \mathrm{H}, \mathrm{s})$. MS (FAB): $m / z 380(\mathrm{M}+\mathrm{H})^{+}$.

1-[3-(tert-Butyldimethylsilyloxymethyl)-5-nitrobenzoyl]-4-(7-diethylaminocoumarin-3-carbonyl)piperazine (14) To a solution of 7-diethylaminocoumarin-3-carboxylic acid ${ }^{18)}(209 \mathrm{mg}, 0.800 \mathrm{mmol})$ in dimethylformamide (DMF) $(4.0 \mathrm{ml})$ was added $1,1^{\prime}$-carbonylbis- $1 H$-imidazole $(156 \mathrm{mg}$, $0.960 \mathrm{mmol}$ ) and the mixture was stirred at ambient temperature for $40 \mathrm{~min}$. To this was added $13(334 \mathrm{mg}, 0.880 \mathrm{mmol})$ and the mixture was stirred at the same temperature for $22 \mathrm{~h}$. The reaction was quenched by adding $\mathrm{H}_{2} \mathrm{O}$ and brine, and the resulting precipitate was collected by filtration, and dried in vacuo. The product was purified by silica-gel column chromatography $\left(\mathrm{CH}_{2} \mathrm{Cl}_{2} /\right.$ ethyl acetate $\left.=5 / 2\right)$ to give 1-[3-(tert-butyldimethylsilyloxymethyl $)$ 5-nitrobenzoyl]-4-(7-diethylaminocoumarin-3-carbonyl)piperazine (14) (488 mg, $0.783 \mathrm{mmol}, 98 \%)$ as a yellow foam; ${ }^{1} \mathrm{H}-\mathrm{NMR}\left(\mathrm{CDCl}_{3}\right) \delta: 0.12$ $(6 \mathrm{H}, \mathrm{s}), 0.94(9 \mathrm{H}, \mathrm{s}), 1.21(6 \mathrm{H}, \mathrm{t}, J=7.0 \mathrm{~Hz}), 3.35-4.00(8 \mathrm{H}, \mathbf{b r}), 3.42(4 \mathrm{H}$, q, $J=7.0 \mathrm{~Hz}), 4.82(2 \mathrm{H}, \mathrm{s}), 6.45(1 \mathrm{H}, \mathrm{br} \mathrm{s}), 6.59(1 \mathrm{H}, \mathrm{d}, J=9.0 \mathrm{~Hz}), 7.29(1 \mathrm{H}$ d, $J=9.0 \mathrm{~Hz}), 7.68(1 \mathrm{H}, \mathrm{s}), 7.90(1 \mathrm{H}, \mathrm{s}), 8.13(1 \mathrm{H}, \mathrm{br} \mathrm{s}), 8.25(1 \mathrm{H}, \mathrm{s}) . \mathrm{MS}$ (FAB): $m / z 623(\mathrm{M}+\mathrm{H})^{+}$

1-[3-Amino-5-(hydroxymethyl)benzoyl]-4-(7-diethylaminocoumarin3-carbonyl)piperazine (15) To a solution of $14(203 \mathrm{mg}, 0.326 \mathrm{mmol})$ in ethyl acetate $(3.0 \mathrm{ml})$ was added $\mathrm{SnCl}_{2} \cdot 2 \mathrm{H}_{2} \mathrm{O}(210 \mathrm{mg}, 0.931 \mathrm{mmol})$ and the mixture was refluxed for $7 \mathrm{~h}$. The reaction was quenched by adding saturate aqueous $\mathrm{NaHCO}_{3}$ solution and the resulting precipitate was removed by filtration through a pad of Celite. The filtrate was extracted with $\mathrm{CH}_{2} \mathrm{Cl}_{2}$, dried $\left(\mathrm{MgSO}_{4}\right)$, and concentrated under reduced pressure. The crude product was purified by silica-gel column chromatography $\left(\mathrm{CH}_{2} \mathrm{Cl}_{2} /\right.$ methanol $=19 / 1$ then 9/1) to give 1-[3-amino-5-(hydroxymethyl)-benzoyl]-4-(7-diethylaminocoumarin-3-carbonyl)piperazine (15) $(153 \mathrm{mg}, 0.319 \mathrm{mmol}, 98 \%)$ as a yellow foam; ${ }^{1} \mathrm{H}-\mathrm{NMR}\left(\mathrm{CDCl}_{3}\right) \delta: 1.20(6 \mathrm{H}, \mathrm{t}, J=7.0 \mathrm{~Hz}), 1.84(1 \mathrm{H}, \mathrm{brs})$, $3.25-3.95(10 \mathrm{H}, \mathrm{br}), 3.41(4 \mathrm{H}, \mathrm{q}, J=7.0 \mathrm{~Hz}), 4.59(2 \mathrm{H}, \mathrm{br} \mathrm{s}), 6.45(1 \mathrm{H}, \mathrm{br}$ s), $6.58(1 \mathrm{H}, \mathrm{d}, J=9.0 \mathrm{~Hz}), 6.59(1 \mathrm{H}, \mathrm{s}), 6.72(2 \mathrm{H}, \mathrm{s}), 7.28(1 \mathrm{H}, \mathrm{d}$, $J=9.0 \mathrm{~Hz}), 7.87(1 \mathrm{H}, \mathrm{s})$. MS (FAB): $m / z 479(\mathrm{M}+\mathrm{H})^{+}$.

1-[3-Azido-5-(hydroxymethyl)benzoyl]-4-(7-diethylaminocoumarin-3carbonyl)piperazine (16) To a solution of $15(312 \mathrm{mg}, 0.651 \mathrm{mmol})$ in $4 \mathrm{~N}$ $\mathrm{HCl}(5.0 \mathrm{ml})$ was added $\mathrm{NaNO}_{2}(89.8 \mathrm{mg}, 1.30 \mathrm{mmol})$ and the mixture was stirred at $0{ }^{\circ} \mathrm{C}$. After $10 \mathrm{~min}, \mathrm{NaN}_{3}(84.6 \mathrm{mg}, 1.30 \mathrm{mmol})$ was added, and the mixture was stirred for $20 \mathrm{~min}$ at the same temperature. The reaction was quenched by adding $\mathrm{NaHCO}_{3}$ powder, and the resulting precipitate was collected by filtration and dried in vacuo to give 1-[3-azido-5-(hydroxymethyl)benzoyl]-4-(7-diethylaminocoumarin-3-carbonyl)piperazine

(16) (304 mg, $0.603 \mathrm{mmol}, 93 \%$ ) as a yellow solid; mp 108-111 ${ }^{\circ} \mathrm{C} .{ }^{1} \mathrm{H}-\mathrm{NMR}$ $\left(\mathrm{CDCl}_{3}\right) \delta: 1.20(6 \mathrm{H}, \mathrm{t}, J=7.0 \mathrm{~Hz}), 2.01(1 \mathrm{H}, \mathrm{br} \mathrm{s}), 3.20-4.00(8 \mathrm{H}, \mathrm{br}), 3.41$ $(4 \mathrm{H}, \mathrm{q}, J=7.0 \mathrm{~Hz}), 4.70(2 \mathrm{H}, \mathrm{br} \mathrm{s}), 6.45(1 \mathrm{H}, \mathrm{br} \mathrm{s}), 6.59(1 \mathrm{H}, \mathrm{d}, J=9.0 \mathrm{~Hz})$, $6.95(1 \mathrm{H}, \mathrm{s}), 7.10(1 \mathrm{H}, \mathrm{s}), 7.13(1 \mathrm{H}, \mathrm{s}), 7.29(1 \mathrm{H}, \mathrm{d}, J=9.0 \mathrm{~Hz}), 7.88(1 \mathrm{H}, \mathrm{s})$. MS (FAB): $m / z 505(\mathrm{M}+\mathrm{H})^{+}$.

1-[3-Azido-5-(bromomethyl)benzoyl]-4-(7-diethylaminocoumarin-3carbonyl)piperazine (17) To a solution of $16(20.0 \mathrm{mg}, 0.040 \mathrm{mmol})$ in $\mathrm{CH}_{2} \mathrm{Cl}_{2}(0.5 \mathrm{ml})$ was added $\mathrm{CBr}_{4}(26.5 \mathrm{mg}, 0.080 \mathrm{mmol})$ and tri- $n$-octylphosphine $(42.0 \mathrm{mg}, 0.113 \mathrm{mmol})$, and the mixture was stirred for $2 \mathrm{~h}$ at the ambient temperature. The reaction mixture was directly applied to silica-gel and the product was purified by silica-gel column chromatography $\left(\mathrm{CH}_{2} \mathrm{Cl}_{2} /\right.$ acetone $\left.=9 / 1\right)$ to give 1-[3-azido-5-(bromomethyl)benzoyl]-4-(7-diethylaminocoumarin-3-carbonyl)piperazine (17) $(13.2 \mathrm{mg}, 0.023 \mathrm{mmol}$, $59 \%)$ as a yellow foam; ${ }^{1} \mathrm{H}-\mathrm{NMR}\left(\mathrm{CDCl}_{3}\right) \delta: 1.21(6 \mathrm{H}, \mathrm{t}, J=7.0 \mathrm{~Hz}), 3.23$ $3.95(8 \mathrm{H}, \mathrm{br}), 3.42(4 \mathrm{H}, \mathrm{q}, J=7.0 \mathrm{~Hz}), 4.42(2 \mathrm{H}, \mathrm{s}), 6.45(1 \mathrm{H}, \mathrm{br} \mathrm{s}), 6.59$ $(1 \mathrm{H}, \mathrm{dd}, J=1.5,9.0 \mathrm{~Hz}), 6.99(1 \mathrm{H}, \mathrm{d}, J=1.5 \mathrm{~Hz}), 7.08(1 \mathrm{H}, \mathrm{br} \mathrm{s}), 7.16(1 \mathrm{H}$, s), $7.29(1 \mathrm{H}, \mathrm{d}, J=9.0 \mathrm{~Hz}), 7.89(1 \mathrm{H}, \mathrm{s})$. MS (FAB): $m / z 567(\mathrm{M}+\mathrm{H})^{+}$.

Fluorescent Photoaffinity Labeling Probe: CAFSA (6) To a solution of $7(28.8 \mathrm{mg}, 0.056 \mathrm{mmol})$ in DMF $(0.3 \mathrm{ml})$ was added NaHMDS $(0.5 \mathrm{M}$ tetrahydrofran (THF) solution, $100 \mu \mathrm{l}, 0.050 \mathrm{mmol}$ ) at $0{ }^{\circ} \mathrm{C}$ and the mixture was stirred for $1 \mathrm{~h}$ at the same temperature. To this was added a solution of $17(13.2 \mathrm{mg}, 0.023 \mathrm{mmol})$ in DMF $(0.2 \mathrm{ml})$ and the mixture was stirred for $5 \mathrm{~h}$ at the same temperature. The reaction was quenched by adding $\mathrm{H}_{2} \mathrm{O}$ and the mixture was extracted with $\mathrm{CH}_{2} \mathrm{Cl}_{2}$, dried $\left(\mathrm{MgSO}_{4}\right)$, and concentrated under reduced pressure. The product was purified by silica-gel column chromatography $\left(\mathrm{CH}_{2} \mathrm{Cl}_{2} /\right.$ methanol $\left.=9 / 1\right)$ to give CAFSA (6) $(2.5 \mathrm{mg}$, $0.003 \mathrm{mmol}, 12 \%$ ) as a yellow oil; ${ }^{1} \mathrm{H}-\mathrm{NMR}$ (acetone- $\left.d_{6}\right) \delta: 0.84(3 \mathrm{H}, \mathrm{d}$, $J=6.5 \mathrm{~Hz}), 1.15(2 \mathrm{H}, \mathrm{br} \mathrm{s}), 1.21(6 \mathrm{H}, \mathrm{t}, J=7.0 \mathrm{~Hz}), 1.26(3 \mathrm{H}, \mathrm{s}), 1.52-1.80$
$(5 \mathrm{H}, \mathrm{m}), 1.57(1 \mathrm{H}, \mathrm{ddd}, J=3.0,10.5,13.5 \mathrm{~Hz}), 1.65(3 \mathrm{H}, \mathrm{s}), 1.71(3 \mathrm{H}, \mathrm{s})$, $1.90-1.99(1 \mathrm{H}, \mathrm{m}), 2.09-2.22(5 \mathrm{H}, \mathrm{m}), 2.42-2.52(1 \mathrm{H}, \mathrm{m}), 2.65-2.70$ $(1 \mathrm{H}, \mathrm{br}), 2.86(1 \mathrm{H}, \mathrm{d}, J=6.0 \mathrm{~Hz}), 3.40-3.90(14 \mathrm{H}, \mathrm{br}), 3.53(4 \mathrm{H}, \mathrm{q}$, $J=7.0 \mathrm{~Hz}), 4.53(1 \mathrm{H}, \mathrm{d}, J=12.5 \mathrm{~Hz}), 4.57(1 \mathrm{H}, \mathrm{d}, J=12.5 \mathrm{~Hz}), 5.16-5.30$ $(1 \mathrm{H}, \mathrm{m}), 5.21(1 \mathrm{H}, \mathrm{dd}, J=10.5,15.0 \mathrm{~Hz}), 5.91(1 \mathrm{H}, \mathrm{d}, J=10.5 \mathrm{~Hz}), 6.20$ $6.32(1 \mathrm{H}, \mathrm{m}), 6.52(1 \mathrm{H}, \mathrm{s}), 6.76(1 \mathrm{H}, \mathrm{dd}, J=2.0,9.0 \mathrm{~Hz}), 7.06(1 \mathrm{H}, \mathrm{s}), 7.15$ $(1 \mathrm{H}, \mathrm{s}), 7.24(1 \mathrm{H}, \mathrm{s}), 7.47(1 \mathrm{H}, \mathrm{d}, J=9.0 \mathrm{~Hz}), 7.88(1 \mathrm{H}, \mathrm{d}, J=2.0 \mathrm{~Hz})$. HRMS [FAB, $(\mathrm{M}-\mathrm{H})^{+}$] Calcd for $\mathrm{C}_{51} \mathrm{H}_{63} \mathrm{~N}_{6} \mathrm{O}_{8}$ : 887.4707, Found: 887.4675.

PhotoAffinity Labeling Soluble cytosolic fraction of HL-60 cells $(0.2 \mathrm{mg} / \mathrm{ml}$, prepared as described above) was incubated with the photoaffinity probe CAFSA $(6)(10 \mu \mathrm{M})$ in a $0.6 \mathrm{ml}$ Eppendorf tube in the presence or absence of fusarielin A (FSA) $(1 \mathrm{mM})$. The mixture (final volume $=200 \mu \mathrm{l}$ ) was photoirradiated with UV light $(254 \mathrm{~nm}, 4 \mathrm{~W}$, UVP UVGL-25) for $5 \mathrm{~min}$ from a distance of $1.7 \mathrm{~cm}$ at $25^{\circ} \mathrm{C}$. A part of the mixture $(100 \mu \mathrm{l})$ was decanted onto gel (Sephadex G-25 Medium) and gel filtration was carried out using Tris-buffer $(20 \mathrm{~mm}$ Tris $-\mathrm{HCl}, 600 \mathrm{~mm} \mathrm{KCl}, 5 \mathrm{~mm}$ dithiothreitol (DTT), $\mathrm{pH}$ 7.5) as the eluent. The eluates were collected in fractions of 3 drops (about $100 \mu \mathrm{l}$ ) and the fluorescence intensity of each fraction was measured.

\section{References}

1) Iwasaki S., Kobayashi H., Furukawa J., Namikoshi M., Okuda S., Sato Z., Matsuda I., Noda T., J. Antibiot., 37, 354-362 (1984).

2) David-Pfeuty T., Simon C., Pantaloni D., J. Biol. Chem., 254, 1169611702 (1979).

3) Friedman P. A., Platzer E. G., Biochem. Biophys. Acta, 544, 605-614 (1978).

4) Namikoshi M., Kobayashi H., Yoshimoto T., Hosoya T., J. Antibiot., 50, 890-892 (1997).

5) Dixon N., Wong L. S., Geerlings T. H., Micklefield J., Nat. Prod. Rep., 24, 1288-1310 (2007).

6) Baker D. D., Chu M., Oza U., Rajgarhia V., Nat. Prod. Rep., 24, 1255-1244 (2007)

7) Kobayashi H., Sunaga R., Furihata K., Morisaki N., Iwasaki S., J. Antibiot., 48, 42-52 (1995).

8) Kobayashi H., Namikoshi M., Yoshimoto T., Yokochi T., J. Antibiot., 49, 873-879 (1996).

9) Kumagai H., Someno T., Dobashi K., Isshiki K., Ishizuka M., Ikeda D., J. Antibiot., 57, 97-103 (2004)

10) Someno T., Kumagai H., Ohba S., Amemiya M., Naganawa H., Ishizuka M., Ikeda D., J. Antibiot., 57, 104-109 (2004).

11) Ng S. S. W., Gutschow M., Weiss M., Hauschildt S., Teubert U., Hecker T. K., Luzzio F. A., Kruger E. A., Eger K., Figg W. D., Cancer Res., 63, 3189-3194 (2003).

12) Hosoya T., Aoyama H., Ikemoto T., Hiramatsu T., Kihara Y., Endo M., Suzuki M., Bioorg. Med. Chem. Lett., 12, 3263-3265 (2002).

13) Hashimoto Y., Kagechika H., Kawachi E., Shudo K., Jpn. J. Cancer Res. (Gann), 79, 473-483 (1988).

14) Hashimoto Y., Shudo K., Biochem. Biophys. Res. Commun., 166, 1126-1132 (1990).

15) Hashimoto Y., Shudo K., J. Cancer Res., 82, 665-675 (1991).

16) Parlow J. J., Case B. L., Dice T. A., Fenton R. L., Hayes M. J., Jones D. E., Neumann W. L., Wood R. S., Lachance R. M., Girard T. J., Nicholson N. S., Clare M., Stegeman R. A., Stevens A. M., Stallings W. C., Kurumbail R. G., South M. S., J. Med. Chem., 46, 4050-4062 (2003).

17) Watzke A., Gutierrez-Rodriguez M., Köhn M., Wacker R., Schroeder H., Breinbauer R., Kuhlmann J., Alexandrov K., Niemeyer C. M., Goody R. S., Waldmann H., Bioorg. Med. Chem., 14, 6288-6306 (2006).

18) Ma Y., Luo W., Quinn P. J., Liu Z., Hider R. C., J. Med. Chem., 47, $6349-6362$ (2004).

19) Shimazawa R., Sanda R., Mizoguchi H., Hashimoto Y., Iwasaki S., Tanaka H., Kagechika H., Shudo K., Biochem. Biophys. Res. Commun., 179, 259-265 (1991).

20) Sawada T., Kobayashi H., Hashimoto Y., Iwasaki S., Biochem. Pharmacol., 45, 1387-1394 (1993).

21) Sawada T., Kato Y., Kobayashi H., Hashimoto Y., Watanabe T., Sugiyama Y., Iwasaki S., Bioconjugate Chem., 4, 284-289 (1993). 